\author{
Mooy, H. • A. Nuraini · Sumadi
}

\title{
Respons perkecambahan benih jagung manis terhadap konsentrasi dan lama perendaman giberelin pada suhu lingkungan yang berbeda
}

Sari. Penanaman jagung manis pada daerah dengan suhu rendah dapat menyebabkan cekaman pada kecambah, sehingga performa kecambah perlu ditingkatkan. Penelitian ini bertujuan untuk menganalisis pengaruh interaksi antara konsentrasi giberelin $\left(\mathrm{GA}_{3}\right)$ dan lama waktu perendaman benih pada suhu lingkungan tertentu terhadap pertumbuhan kecambah jagung manis. Penelitian ini dilaksanakan pada Laboratorium Teknologi Benih Fakultas Pertanian, Universitas Padjadjaran Bandung pada bulan Juni 2019. Rancangan percobaan menggunakan Rancangan Acak Kelompok pola faktorial dengan dua faktor dan tiga ulangan. Faktor perlakuan adalah konsentrasi $\mathrm{GA}_{3}$ dan lama perendaman. Faktor konsentrasi giberelin terdiri dari 50 ppm, 100 ppm dan 150 ppm, sedangkan faktor lamaperendaman terdiri dari 3 jam, 6 jam, dan 9 jam.Percobaan dilakukan pada dua suhu lingkungan yang berbeda, yaitu $16-18^{\circ} \mathrm{C}$ dan $20-$ $22^{\circ} \mathrm{C}$. Peubah yang diamati adalah daya berkecambah, kecepatan tumbuh, keserempakan tumbuh, dan potensi tumbuh maksimum. Analisis data menggunakan uji Jarak Berganda Duncan pada taraf nyata 5\%. Hasil penelitian menunjukkan bahwa terjadi pengaruh interaksi antara konsentrasi giberelin dan lama perendaman. Pemberian giberelin pada benih dapat meningkatkan performa kecambah baik pada suhu $16-18^{\circ} \mathrm{C}$ maupun $20-22^{\circ} \mathrm{C}$.Perlakuan giberelin $100 \mathrm{ppm}$ dengan lama perendaman 6 jam menunjukkan performa kecambah yang paling baik.

Kata kunci: Jagung manis · Konsentrasi giberelin $\cdot$ Lama perendaman

\section{The germination response of sweet corn seed to the concentration level and soaking time of gibberelin at different temperatures}

\begin{abstract}
Sweet corn cultivation in areas with low temperatures can cause stress on the sprouts, so its performance needs to be improved. This study aims to analyze the interaction effect between gibberellin (GA3) the concentration and the time of seeds soaking in GA3 at various temperatures on the growth of sweet corn sprouts. This research was conducted at the Laboratory of Seed Technology, Faculty of Agriculture, Universitas Padjadjaran, in June 2019. The experimental design used a factorial randomized block designwith two factors and three replications. The treatment factors were the concentration of GA3 and the time of seeds soaking in GA3. The gibberellin concentration consisted of $50 \mathrm{ppm}, 100 \mathrm{ppm}$, and 150 ppm, while the soaking time consisted of 3 hours, 6 hours, and 9 hours. Experiments were carried out at two different temperatures, there were $16-18^{\circ} \mathrm{C}$ and $20-22^{\circ} \mathrm{C}$. The observed variables were germination rate, sprout growth rate, synchronous growth, and maximum growth potential. Data was analyzed by Duncan's Multiple Range test at the 5\% significant level. The results showed that there was an interaction effect between the concentration of GA3 and the time of seeds soaking in GA3. Gibberellin application to seeds can improve the performance of sprouts both at $16-18^{\circ} \mathrm{C}$ and $20-22^{\circ} \mathrm{C}$. Gibberellin treatment of $100 \mathrm{ppm}$ and soaking time for 6 hours showed the best performance of sprouts.
\end{abstract}

Keywords: Gibberellins concentration · Soaking time · Sweet corn

Diterima : 24 Januari 2020, Disetujui : 14 April 2021, Dipublikasikan : 16 April 2021 doi: https://doi.org/10.24198/kultivasi.v20i1.30705

\footnotetext{
Mooy, H. ${ }^{1} \cdot$ A. Nuraini ${ }^{2}$ Sumadi ${ }^{2}$

${ }^{1}$ Kementerian Pertanian, ${ }^{2}$ Fakultas Pertanian Universitas Padjajaran Bandung

Korespondensi: herlistin@pertanian.go.id xx 100\%
} 


\section{Pendahuluan}

Jagung manis (Zea mays var. Saccharata Sturt) merupakan komoditas pertanian yang sangat digemari karena rasanya yang manis, mudah diolah, mengandung sedikit protein dan lemak. Selain bijinya yg manis, butiran jagung lebih khas, tidak lembek dan memiliki serat yang tidak terlalu liat sehingga banyak digemari semua kalangan masyarakat (Putri, 2011). Jagung manis juga mempunyai peranan cukup besar dalam memenuhi kebutuhan gizi masyarakat (Novira et al., 2015).

Produksi jagung manis di Indonesia masih rendah. Menurut Badan Pusat Statistik (2015) produktivitas rata-rata mencapai 5,19 ton/ha, padahal menurut Syukur dan Rifianto (2013), tanaman jagung manis memiliki potensi hasil sampai 20 ton/ha. Rendahnya produktivitas jagung manis saat ini terjadi karena kurangnya perhatian petani dalam memanfaatkan lahan pertanian, teknik budidaya yang belum maksimal, dan lahan-lahan subur yang beralih fungsi untuk tanaman industri maupun pemukiman (Bakrie, 2006).

Berbagai upaya peningkatan produksi jagung manis dalam negeri terus dilakukan pemerintah melalui pendekatan intensifikasi (perbaikan teknik budidaya dan penggunaan benih unggul) maupun ekstensifikasi (Nirmala, 2012). Salah satu upaya yang dilakukan untuk memenuhi kebutuhan jagung manis di dalam negeri adalah dengan melakukan ekstensifikasi lahan pada dataran medium dan dataran tinggi. Upaya ini tidak mudah dilakukan, karena untuk memindahkan suatu usaha budidaya tanaman dari dataran rendah ke dataran tinggi berkaitan dengan syarat tumbuh tanaman. Ketingian suatu tempat berkorelasi terbalik dengan suhu lingkungan, semakin tinggi ketinggian suatu tempat maka suhu lingkungan akan semakin rendah (Miedema, 1982). Suhu lingkungan berpengaruh pada aktivitas fisiologi tanaman seperti pertumbuhan akar, serapan unsur hara dan air dalam tanah, fotosintesis, respirasi dan translokasi fotosintat (Miedema, 1982). Selain itu, suhu udara dan atau suhu tanah juga berpengaruh terhadap dormansi benih, perkecambahan, laju pertumbuhan, pembungaan, pertumbuhan buah, dan pematangan jaringan tanaman. (Yamaguci, 2008).

Hasil penelitian Miedema (1982) dan Farooq et al. (2009) melaporkan bahwa proses perkecambahan jagung manis akan terhambat jika ditanam di suhu dingin sehingga mempengaruhi produktivitas. Lesilolo et al. (2013) dan Tefa (2017) menyatakan bahwa keseragaman perkecambahan sangat penting untuk mendapatkan hasil yang tinggi. Perkecambahan tidak seragam jika daya tumbuh benih rendah. Benih jagung yang terlambat tumbuh akan ternaungi dan pertumbuhannya bersaing dengan gulma. Akibatnya jagung tumbuh tidak normal dan tongkolnya relatif lebih kecil dibanding jagung yang tumbuh lebih awal dan seragam.

Giberelin $\left(\mathrm{GA}_{3}\right)$ merupakan suatu senyawa organik yang sangat penting dalam proses perkecambahan benih pada umumnya, demikian pula pada benih jagung dan serealia lainnya. Dalam proses perkecambahan, giberelin berfungsi untuk meningkatkan potensi tumbuh dari embrio dan sebagai promotor perkecambahan, mengatasi hambatan mekanik oleh lapisan penutup benih, karena terdapatnya jaringan di sekeliling radikula dan mendorong aktivitas enzim-enzim hidrolitik pada proses perkecambahan (Kucera et al., 2005; Weiss and Ori, 2007).

Beberapa penelitian dilaporkan bahwa terjadi respon positif zat pengatur tumbuh giberelin $\left(\mathrm{GA}_{3}\right)$ terhadap viabilitas vigor benih, bahkan performa yang sama juga ditunjukkan oleh benih yang tercekam (Kamil, 1979; Kucera et al., 2005; Weiss dan Ori, 2007; Yanfang et al., 2017). Mukti (2013) menyatakan lama perendaman benih jagung pada larutan giberelin berpengaruh sangat nyata terhadap potensi tumbuh, daya berkecambah, kecepatan tumbuh, keserempakan tumbuh dan vigor kecambah benih jagung kadaluarsa. Potensi tumbuh tertinggi dijumpai pada lama perendaman 3 jam, tetapi daya berkecambah, kecepatan tumbuh, keserempakan tumbuh, dan vigor kecambah tertinggi dijumpai pada lama perendaman 6 jam. Untuk meningkatkan perkecambahan jagung manis di dataran rendah dan medium, perlu dilakukan penelitian untuk mengetahui pengaruh interaksi antara konsentrasi dan lama perendaman giberelin $\left(G_{3}\right)$ pada benih jagung manisdi suhu rendah.

\section{Bahan dan Metode}

Penelitian ini dilaksanakan di Laboratorium Teknologi Benih, Fakultas Petanian Universitas Padjajaran pada bulan Juni 2019. Bahan yang digunakan dalam percobaan ini antara lain: benih jagung manis kultivar Talenta, Zat 
pengatur tumbuh $\mathrm{GA}_{3}$ (GibGro $10 \mathrm{SP}$ ), aquades, dan kertas merang. Alat yang digunakan dalam percobaan ini, antara lain: pengepres kertas, germinator, oven, kulkas, penjepit, timbangan analitik, gunting, mistar, pinset, wadah merendam, label, alat tulis menulis, dan peralatan laboratorium lainnya yang mendukung. Percobaan dilakukan pada suhu yang berbeda yaitu suhu $16-18{ }^{\circ} \mathrm{C}$ dan suhu $20-$ $22{ }^{\circ} \mathrm{C}$ dan $\mathrm{RH}$ rata-rata sekitar $78 \%$.

Rancangan percobaan yang digunakan adalah Rancangan Acak Kelompok (RAK) faktorial dengan dua faktor dan diulang tiga kali. Faktor pertama adalah konsentrasiGA, terdiri dari empat perlakuan yaitu: $\mathrm{g}_{0}=$ kontrol (0 ppm), $\mathrm{g}_{1}=50 \mathrm{ppm}, \mathrm{g}_{2}=100 \mathrm{ppm}$, dan $\mathrm{g}_{3}=150$ ppm, sedangkan faktor kedua adalah lama perendaman, terdiri dari empat perlakuan yaitu: $\mathrm{p}_{0}=\operatorname{kontrol}(0 \mathrm{jam}), \mathrm{p}_{1}=3 \mathrm{jam}, \mathrm{p}_{2}=6$ jam, dan $\mathrm{p}_{3}$ $=9$ jam.Percobaan terdiri dari dua set percobaan yaitu pengujian benih setelah perlakuan giberelin pada suhu $16-18{ }^{\circ} \mathrm{C}$ (rata-rata suhu di dataran tinggi) dan suhu $20-22{ }^{\circ} \mathrm{C}$ (rata-rata suhu di dataran medium)

Prosedur pelaksanaan metode uji viabilitas benih yaitu dengan menggunakan Uji Kertas Digulung didirikan dalam plastik (UKDdp). Kertas merang disiapkan dan dibasahkan terlebih dahulu dengan aquades. Selanjutnya kertas tersebut dipress dengan alat pengepres kertas sampai kertas menjadi lembab. Benih ditanam di atas 3 media kertas yang bawahnya telah dilapisi plastik lalu ditutup dengan 2 lembar kertas, kemudian digulung, dan diberi label. Gulungan kertas yang berisi 50 benih diletakkan dengan cara ditegakkan. Benih kemudian dikecambahkan di 2 tempat dengan suhu yang berbeda yaitu di ruangan dengan suhu kamar/germinator $20-25{ }^{\circ} \mathrm{C}$ dan di ruangan ber-AC dengan suhu $16-18^{\circ} \mathrm{C}$. Benih dikecambahkan selama 7 hari kemudian dilakukan pengamatan mulai hari ke 4 hingga hari ke 7 .

Parameter pengamatan meliputi daya berkecambah, potensi tumbuh maksimum, berat kering kecambah normal, kecepatan tumbuh, indeks vigor, tinggi plumula, panjang radikula dan berat kering kecambah normal.

a) Daya Berkecambah (DB)

Pengamatan ini dilakukan pada hari ke 4 hingga hari ke 7 setelah tanam. Persentase kecambah normal dihitung dengan rumus (Sutopo, 2012):

$$
D B=\frac{\Sigma \text { Kecambah normal pengamatan }}{\Sigma \text { Benih yang dikecambahkan }} \times 100 \%
$$

b) Kecepatan Tumbuh $\left(\mathrm{K}_{\mathrm{CT}}\right)$

Kecepatan tumbuh dihitung berdasarkan akumulasi persentase kecambah normal per etmal (24 jam) selama periode perkecambahan yaitu sampai hari ke-7 dengan rumus sebagai berikut (Sutopo, 2012):

$$
K c t=\sum_{t=0}^{t=n} \frac{N}{t}
$$

Keterangan :

$\mathrm{N}$ : persentase kecambah normal (\%)

$\mathrm{T}$ : waktu pengamatan dalam etmal

c) Keserampakan Tumbuh( $\left.\mathrm{K}_{\mathrm{ST}}\right)$

Perhitungan keserampakan tumbuh dilakukan terhadap kecambah normal kuat pada hari ke-6, yaitu antara pengamatan I (hari ke-4) dan pengamatan II (hari ke-7) setelah tanam dan dinyatakan dalam persen. Keserampakan tumbuh menggunakan rumus persamaan sebagai berikut (Sutopo, 2012):

$$
K s T=\frac{\sum \text { Kecambah normal kuat }}{\Sigma \text { Benih yang ditanam }}
$$

d) Potensi Tumbuh Maksimal (PTM)

Potensi tumbuh dihitung berdasarkan persentase benih berkecambah pada akhir pengamatan, yaitu pada hari ke-7 setelah pengecambahan. Pengecambahan benih dilakukan dengan metode sama dengan pengujian daya berkecambah. Rumus perhitungan sebagai berikut (Sutopo, 2012):

$$
P T M=\frac{\Sigma \text { Benih yang tumbuh }}{\text { DBenih yang ditanam }} \times 100 \%
$$

Data yang diperoleh kemudian dianalisis sidik ragam menggunakan software SPSS. Apabila nilai $\mathrm{F}$ hitung menunjukkan pengaruh nyata, maka akan dilanjutkan dengan Duncan Multiple Range Test (DMRT) pada tarafnyata5\%(Gomez dan Gomez, 1995).

\section{Hasil dan Pembahasan}

Hasil perhitungan analisis ragam pada pengaruh perlakuan konsentrasi giberelin dan lama perendaman secara keseluruhan berpengaruh nyata terhadap peubah viabilitas dan vigor benih jagung manis pada baik pada suhu 16-18 ${ }^{\circ} \mathrm{C}$ dan $20-25^{\circ} \mathrm{C}$. 
Tabel 1. Analisis ragam pengaruh perlakuan konsentrasi giberelin dan lama perendaman terhadap viabilitas dan vigor benih jagung manis pada suhu $16-18^{\circ} \mathrm{C}$ dan $20-25^{\circ} \mathrm{C}$.

\begin{tabular}{|c|c|c|c|c|c|c|}
\hline \multirow{3}{*}{$\begin{array}{c}\text { Peubah } \\
\text { Pengamatan }\end{array}$} & \multicolumn{6}{|c|}{ Perlakuan dan Interaksinya } \\
\hline & \multicolumn{3}{|c|}{ Suhu $16^{\circ}-18^{\circ} \mathrm{C}$} & \multicolumn{3}{|c|}{ Suhu $20^{\circ}-25^{\circ} \mathrm{C}$} \\
\hline & $\begin{array}{l}\text { Konsentrasi } \\
\text { GA3 (ppm) }\end{array}$ & $\begin{array}{c}\text { Lama } \\
\text { Perendaman } \\
\text { (jam) }\end{array}$ & $\begin{array}{l}\text { Konsentrasi } \\
\text { GA3 x Lama } \\
\text { Perendaman }\end{array}$ & $\begin{array}{l}\text { Konsentrasi } \\
\text { GA3 (ppm) }\end{array}$ & $\begin{array}{c}\text { Lama } \\
\text { Perendaman } \\
\text { (jam) }\end{array}$ & $\begin{array}{l}\text { Konsentrasi } \\
\text { GA3 x Lama } \\
\text { Perendaman }\end{array}$ \\
\hline DB & * & * & * & * & * & * \\
\hline $\mathrm{K}_{\mathrm{CT}}$ & * & * & * & * & * & * \\
\hline $\mathrm{K}_{\mathrm{ST}}$ & * & * & * & * & * & * \\
\hline PTM & * & * & * & * & * & * \\
\hline
\end{tabular}

Berbeda nyata pada taraf nyata 0.05

Tabel 1. Pengaruh interaksi perlakuan konsentrasi giberelin dan lama perendaman terhadap persentase daya kecambah (DB) pada suhu $16-18^{\circ} \mathrm{C}$.

\begin{tabular}{ccccc}
\hline Lama Perendaman & \multicolumn{4}{c}{ Daya kecambah $(\%)$} \\
\cline { 2 - 5 } KonsentrasiGA 3 & $\mathrm{p}_{0}(0 \mathrm{jam})$ & $\mathrm{p}_{1}(3 \mathrm{jam})$ & $\mathrm{p}_{2}(6$ jam $)$ & $\mathrm{p}_{3}(9$ jam $)$ \\
\hline \multirow{2}{*}{$\mathrm{g}_{0}(0 \mathrm{ppm})$} & $70.00 \mathrm{c}$ & $75.00 \mathrm{c}$ & $81.00 \mathrm{~d}$ & $71.00 \mathrm{~b}$ \\
& $\mathrm{C}$ & $\mathrm{B}$ & $\mathrm{A}$ & $\mathrm{C}$ \\
$\mathrm{g}_{1}(50 \mathrm{ppm})$ & $74.33 \mathrm{~b}$ & $81.00 \mathrm{~b}$ & $92.00 \mathrm{~b}$ & $\mathrm{~B}$ \\
& $\mathrm{C}$ & $\mathrm{B}$ & $\mathrm{A}$ & $85.33 \mathrm{a}$ \\
$\mathrm{g}_{2}(100 \mathrm{ppm})$ & $81.00 \mathrm{a}$ & $92.00 \mathrm{a}$ & $98.67 \mathrm{a}$ & $\mathrm{B}$ \\
& $\mathrm{D}$ & $\mathrm{B}$ & $\mathrm{A}$ & $74.33 \mathrm{~b}$ \\
\hline
\end{tabular}

Keterangan : Angka yang diikuti dengan huruf kecil yang sama pada kolom yang sama atau huruf kapital yang sama bada baris yang sama menunjukkan tidak berbedanyata menurut uji jarak berganda Duncan pada taraf nyata $5 \%$.

Tabel 2. Pengaruh interaksi perlakuan konsentrasi giberelin dan lama perendaman terhadap persentase daya kecambah (DB) pada suhu $20^{\circ}-22^{\circ} \mathrm{C}$.

\begin{tabular}{ccccc}
\hline \multirow{2}{*}{ Lama Perendaman } & \multicolumn{4}{c}{ Daya Berkecambah $(\%)$} \\
\cline { 2 - 5 } KonsentrasiGA & $\mathrm{p}_{0}(0 \mathrm{jam})$ & $\mathrm{p}_{1}(3 \mathrm{jam})$ & $\mathrm{p}_{2}(6 \mathrm{jam})$ & $\mathrm{p}_{3}(9 \mathrm{jam})$ \\
\hline \multirow{2}{*}{$\mathrm{g}_{0}(0 \mathrm{ppm})$} & $66.67 \mathrm{~b}$ & $77.00 \mathrm{c}$ & $90.00 \mathrm{c}$ & $75.33 \mathrm{c}$ \\
& $\mathrm{B}$ & $\mathrm{B}$ & $\mathrm{A}$ & $\mathrm{B}$ \\
$\mathrm{g}_{1}(50 \mathrm{ppm})$ & $73.33 \mathrm{ab}$ & $84.33 \mathrm{~b}$ & $92.67 \mathrm{~b}$ & $84.33 \mathrm{~b}$ \\
& $\mathrm{C}$ & $\mathrm{B}$ & $\mathrm{A}$ & $\mathrm{B}$ \\
$\mathrm{g}_{2}(100 \mathrm{ppm})$ & $81.33 \mathrm{a}$ & $89.67 \mathrm{a}$ & $99.33 \mathrm{a}$ & $93.00 \mathrm{a}$ \\
& $\mathrm{C}$ & $\mathrm{B}$ & $\mathrm{A}$ & $\mathrm{B}$ \\
$\mathrm{g}_{3}(150 \mathrm{ppm})$ & $76.00 \mathrm{ab}$ & $77.00 \mathrm{c}$ & $85.00 \mathrm{~b}$ & $77.67 \mathrm{c}$ \\
\hline
\end{tabular}

Keterangan : Angka yang diikuti dengan huruf kecil yang sama pada kolom yang sama atau huruf kapital yang sama bada baris yang sama menunjukkan tidak berbedanyata menurut uji jarak berganda Duncan pada taraf nyata $5 \%$.

Pemberian giberelin lebih dari 100 ppm atau lama perendaman lebih dari 6 jam umumnya akan menurunkan daya kecambah benih sama dengan kontrol. Pengaruh interaksi dapat dilihat pada perendaman 9 jam, bahwa pemberian giberelin dengan konsentrasi 150 ppm menurunkan daya berkecambah tetapi lebih baik daripada kontrol. Pengecualian pada suhu $20-22{ }^{\circ} \mathrm{C}$, konsentrasi $150 \mathrm{ppm}$ pada perendaman 9 jam menurunkan daya berkecambah sama dengan kontrol. Uji jarak berganda Duncan menunjukkan bahwa pada konsentrasi GA3100 ppm dengan lama perendaman 6 jam menghasilkan persentase perkecambahan tertinggi yaitu sebesar $98.67 \%$ pada suhu $16-18{ }^{\circ} \mathrm{C}$ dan $99.33 \%$ pada suhu 20 $22^{\circ} \mathrm{C}$ (Tabel 1 dan Tabel 2).

Benih yang direndam dalam waktu lebih dari 6 jam akan mengalami penurunan daya berkecambah. Adanya pengaruh interaksi 
menunjukkan bahwa pemberian konsentrasi giberelin $150 \mathrm{ppm}$ pada benih yang direndam lebih lama dapatmengurangi penurunan daya berkecambahnya. Namun demikian, pemberian giberelin 100 ppm dan lama perendaman 6 jam lebih baik dibandingkan kontrol pada suhu yang berbeda. Hal ini dapat diinterpretasikan bahwa suhu tidak mempengaruhi efek pemberian giberelin terhadap daya berkecambah. Giberelin merupakan faktor utama dalam perkecambahan untuk menghasilkan tanaman yang produktif memuaskan (Bradbeer, 1988; Milosevic, 2010; Sabhan, 2013).

Hasil analisis ragam menunjukkanbahwa terdapat pengaruh interaksi konsentrasi $\mathrm{GA}_{3}$ dan lama perendaman terhadap persentase kecepatan tumbuh (KcT) pada jagung manis. Pengaruh interaksi yang terjadi mirip dengan pengamatan daya berkecambah. Akan tetapi, pada suhu $16-18{ }^{\circ} \mathrm{C}$, pemberian giberelin 150 ppm memiliki efek yang sama dengan kontrol pada waktu perendaman 9 jam. Pada suhu 20$22{ }^{\circ} \mathrm{C}$, kecepatan tumbuh pada 150 ppm lebih baik dibandingkan kontrol pada semua waktu perendaman. Uji DMRT menunjukkanbahwa pada konsentrasi $\mathrm{GA}_{3} 100$ ppm dengan lama perendaman 6 jam menghasilkan persentase kecepatan tertinggi yaitu sebesar $44.33 \%$ pada suhu $16-18{ }^{\circ} \mathrm{C}$ dan $28.67 \%$ pada suhu $20-22{ }^{\circ} \mathrm{C}$ (Tabel 3 dan 4). Peningkatan konsentrasi GA 3 dari 50 sampai 100 ppm mampu meningkatkan viabilitas dayaberkecambah benih jagung manis, dengan lama perendaman 3 jam dan 6 jam. Pada konsentrasi $\mathrm{GA}_{3} 150 \mathrm{ppm}$ dengan lama perendaman 9 jam, daya berkecambah benih sudah tidak menunjukkan pertambahan. Hal ini menunjukkan bahwa perendaman benih dengan waktu yang relatif lama, dengan konsentrasi $\mathrm{GA}_{3}$ yang relatif tinggi cenderung tidak memberikan pengaruh nyata bahkan menurun kembali setara dengan benih tanpa perlakuan perendaman giberelin.

Tabel 3. Pengaruh interaksi perlakuan konsentrasi giberelin dan lama perendaman terhadap persentase kecepatan tumbuh (Kct) pada suhu $16-18^{\circ} \mathrm{C}$.

\begin{tabular}{|c|c|c|c|c|}
\hline \multirow{2}{*}{$\begin{array}{l}\text { Lama Perendaman } \\
\text { KonsentrasiGA }\end{array}$} & \multicolumn{4}{|c|}{ Kecepatan Tumbuh (\%/etmal) } \\
\hline & $\mathrm{p}_{0}(0$ jam $)$ & $\mathrm{p}_{1}(3 \mathrm{jam})$ & $\mathrm{p}_{2}(6$ jam $)$ & $\mathrm{p}_{3}(9$ jam $)$ \\
\hline \multirow{2}{*}{$\mathrm{g}_{0} \quad(0 \mathrm{ppm})$} & $17.33 \mathrm{c}$ & $17.67 \mathrm{c}$ & $21.33 \mathrm{~b}$ & $16.67 \mathrm{c}$ \\
\hline & $\mathrm{B}$ & $\mathrm{CB}$ & $\mathrm{A}$ & $\mathrm{B}$ \\
\hline \multirow{2}{*}{$\mathrm{g}_{1} \quad(50 \mathrm{ppm})$} & $19.33 \mathrm{~b}$ & $21.33 \mathrm{~b}$ & $21.33 \mathrm{~b}$ & $20.00 \mathrm{~b}$ \\
\hline & C & B & A & $\mathrm{C}$ \\
\hline \multirow{2}{*}{$\mathrm{g}_{2}(100 \mathrm{ppm})$} & $22.00 \mathrm{a}$ & $26.00 \mathrm{a}$ & $32.67 \mathrm{a}$ & $22.33 \mathrm{a}$ \\
\hline & B & B & A & B \\
\hline \multirow{2}{*}{$\mathrm{g}_{3}(150 \mathrm{ppm})$} & $16.33 \mathrm{c}$ & $18.00 \mathrm{c}$ & $21.33 \mathrm{~b}$ & $17.67 \mathrm{c}$ \\
\hline & B & B & A & B \\
\hline
\end{tabular}

Keterangan : Angka yang diikuti dengan huruf kecil yang sama pada kolom yang sama atau huruf kapital yang sama bada baris yang sama menunjukkan tidak berbedanyata menurut uji jarak berganda Duncan pada taraf nyata $5 \%$.

Tabel 4. Pengaruh interaksi perlakuan konsentrasi giberelin dan lama perendaman terhadap persentase kecepatan tumbuh (Kct) pada suhu $20-22^{\circ} \mathrm{C}$.

\begin{tabular}{|c|c|c|c|c|}
\hline \multirow{2}{*}{$\begin{array}{l}\text { Lama Perendaman } \\
\text { KonsentrasiGA }_{3}\end{array}$} & \multicolumn{4}{|c|}{ Kecepatan Tumbuh (\%/etmal) } \\
\hline & $\mathrm{p}_{0}(0$ jam $)$ & $\mathrm{p}_{1}(3 \mathrm{jam})$ & $\mathrm{p}_{2}(6$ jam $)$ & $\mathrm{p}_{3}(9$ jam $)$ \\
\hline \multirow{2}{*}{$\mathrm{g}_{0} \quad(0 \mathrm{ppm})$} & $14.67 \mathrm{c}$ & $17.33 \mathrm{c}$ & $21.33 \mathrm{c}$ & $15.33 \mathrm{c}$ \\
\hline & C & B & A & $\mathrm{C}$ \\
\hline \multirow{2}{*}{$\mathrm{g}_{1} \quad(50 \mathrm{ppm})$} & $18.00 \mathrm{~b}$ & $20.33 \mathrm{~b}$ & $23.33 \mathrm{~b}$ & $19.67 \mathrm{~b}$ \\
\hline & $\mathrm{C}$ & B & A & $\mathrm{C}$ \\
\hline \multirow{2}{*}{$\mathrm{g}_{2}(100 \mathrm{ppm})$} & $20.67 \mathrm{a}$ & $24.67 \mathrm{a}$ & $28.67 \mathrm{a}$ & $21.67 \mathrm{a}$ \\
\hline & $\mathrm{C}$ & B & A & $\mathrm{C}$ \\
\hline \multirow{2}{*}{$\mathrm{g}_{3}(150 \mathrm{ppm})$} & $18.33 \mathrm{~b}$ & $20.33 \mathrm{~b}$ & $23.33 \mathrm{~b}$ & $16.00 \mathrm{~b}$ \\
\hline & BC & B & A & C \\
\hline
\end{tabular}

Keterangan : Angka yang diikuti dengan huruf kecil yang sama pada kolom yang sama atau huruf kapital yang sama bada baris yang sama menunjukkan tidak berbedanyata menurut uji jarak berganda Duncan pada taraf nyata $5 \%$. 
Analogi yang sama dengan pengamatan daya berkecambah, bahwa konsentrasi giberelin 100 ppm dan lama perendaman 6 jam meningkatkan kecepatan tumbuh kecambah dan tidak terpengaruh oleh suhu. Kecepatan tumbuh kecambah dapat ditingkatkan menggunakan giberelin untuk menghasilkan tanaman sehat, sebagaimana ditentukan untuk benih yang diuji dalam uji perkecambahan standar, yang memberikan ukuran vigor langsung yang memuaskan (Rusminet al., 2011; Bradbeer, 1988; Milosevic, 2010).

Hasil analisis ragam menunjukkan bahwa terdapat pengaruh interaksi konsentrasi $\mathrm{GA}_{3}$ dan lama perendaman terhadap persentase keserempakan tumbuh dari jagung manis. Pada suhu $16-18{ }^{\circ} \mathrm{C}$, pemberian giberelin lebih dari 100 ppm memberikan efek yangtidak sama dengan kontrol, sementara tidak terdapat efek yang konsisten pada suhu $20-22^{\circ} \mathrm{C}$. Lama perendaman lebih dari 6 jam akan menurunkan keserempakan tumbuh, tapi tidak lebih buruk dibandingkan kontrol pada suhu 16-18 ${ }^{\circ} \mathrm{C}$, sementara pada suhu 20-22 ${ }^{\circ} \mathrm{C}$ memiliki efek yang sama dengan kontrol. Uji jarak berganda Duncan menunjukkan bahwa pada konsentrasi $\mathrm{GA}_{3} 100$ ppm dengan lama perendaman 6 jammenghasilkan persentase keserempakan tumbuh tertinggi yaitu sebesar $98.67 \%$ pada suhu $16-18{ }^{\circ} \mathrm{C}$ dan $99.33 \%$ pada suhu $20-22^{\circ} \mathrm{C}$ (Tabel 5 dan 6).

Giberelin mampu meningkatkan keserempakan tumbuh, baik pada suhu tinggi maupun rendah. Hal ini sesuai dengan penelitian Yanfang et al. (2017) bahwa pemberian giberelin akan memperbaiki performa benih bila ada cekaman, termasuk cekaman suhu. Hal yang hampir serupa dinyatakan oleh Mukti (2013) bahwa keserempakan tumbuh pada jagung kadaluarsa dapat ditingkatkan oleh pemberian giberelin.

Tabel 5. Pengaruh interaksi perlakuan konsentrasi giberelin dan lama perendaman terhadap persentase keserampakan tumbuh pada suhu $16-18^{\circ} \mathrm{C}$.

\begin{tabular}{|c|c|c|c|c|}
\hline \multirow{2}{*}{$\begin{array}{l}\text { Lama Perendaman } \\
\text { KonsentrasiGA } 3\end{array}$} & \multicolumn{4}{|c|}{ Keserempakan Tumbuh (\%) } \\
\hline & $\mathrm{p}_{0}(0$ jam $)$ & $\mathrm{p}_{1}(3 \mathrm{jam})$ & $\mathrm{p}_{2}(6$ jam $)$ & $\mathrm{p}_{3}(9 \mathrm{jam})$ \\
\hline \multirow{2}{*}{$\mathrm{g}_{0} \quad(0 \mathrm{ppm})$} & $70.00 \mathrm{c}$ & $75.00 \mathrm{c}$ & $81.00 \mathrm{~d}$ & $71.00 \mathrm{~b}$ \\
\hline & $\mathrm{C}$ & B & A & $\mathrm{C}$ \\
\hline \multirow{2}{*}{$\mathrm{g}_{1} \quad(50 \mathrm{ppm})$} & $74.33 \mathrm{~b}$ & $81.00 \mathrm{~b}$ & $92.00 \mathrm{~b}$ & $81.00 \mathrm{~b}$ \\
\hline & C & B & A & $\mathrm{B}$ \\
\hline \multirow{2}{*}{$\mathrm{g}_{2}(100 \mathrm{ppm})$} & $81.00 \mathrm{a}$ & $92.00 \mathrm{a}$ & $98.67 \mathrm{a}$ & $85.33 \mathrm{a}$ \\
\hline & $\mathrm{D}$ & B & A & B \\
\hline \multirow{2}{*}{$\mathrm{g}_{3}(150 \mathrm{ppm})$} & $72.00 \mathrm{c}$ & $71.00 \mathrm{~b}$ & $85.00 \mathrm{a}$ & $74.33 \mathrm{~b}$ \\
\hline & B & B & A & B \\
\hline
\end{tabular}

Keterangan : Angka yang diikuti dengan huruf yang sama pada kolom yang sama menunjukkan tidak berbedanyata menurut uji jarak berganda Duncan pada taraf $5 \%$, huruf kapital dibaca arah horizontal dan huruf kecil dibaca arah vertikal.

Tabel 6. Pengaruh interaksi perlakuan konsentrasi giberelin dan lama perendaman terhadap persentase keserampakan tumbuh (KsT) pada suhu $20-22^{\circ} \mathrm{C}$.

\begin{tabular}{|c|c|c|c|c|}
\hline \multirow{2}{*}{$\begin{array}{l}\text { Lama Perendaman } \\
\text { KonsentrasiGA } 3\end{array}$} & \multicolumn{4}{|c|}{ Keserempakan Tumbuh (\%) } \\
\hline & $\mathrm{p}_{0}(0$ jam $)$ & $\mathrm{p}_{1}(3$ jam $)$ & $\mathrm{p}_{2}(6$ jam $)$ & $\mathrm{p}_{3}(9$ jam $)$ \\
\hline $\mathrm{g}_{0} \quad(0 \mathrm{ppm})$ & $\begin{array}{c}66.67 \mathrm{~b} \\
\mathrm{C}\end{array}$ & $\begin{array}{c}77.00 \mathrm{c} \\
\text { B }\end{array}$ & $\begin{array}{c}90.00 \mathrm{c} \\
\mathrm{A}\end{array}$ & $\begin{array}{c}75.33 \mathrm{c} \\
\mathrm{B}\end{array}$ \\
\hline $\mathrm{g}_{1} \quad(50 \mathrm{ppm})$ & $\begin{array}{c}73.00 \mathrm{ab} \\
\mathrm{C}\end{array}$ & $\begin{array}{c}84.33 \mathrm{~b} \\
\mathrm{~B}\end{array}$ & $\begin{array}{c}92.00 \mathrm{~b} \\
\mathrm{~A}\end{array}$ & $\begin{array}{c}83.33 \text { b } \\
\text { B }\end{array}$ \\
\hline $\mathrm{g}_{2}(100 \mathrm{ppm})$ & $\begin{array}{c}81.33 \mathrm{a} \\
\mathrm{C}\end{array}$ & $\begin{array}{c}89.67 \mathrm{a} \\
\text { B }\end{array}$ & $\begin{array}{c}99.33 \mathrm{a} \\
\mathrm{A}\end{array}$ & $\begin{array}{c}91.00 \mathrm{a} \\
\mathrm{B}\end{array}$ \\
\hline $\mathrm{g}_{3}(150 \mathrm{ppm})$ & $\begin{array}{c}76.33 \mathrm{ab} \\
\mathrm{B}\end{array}$ & $\begin{array}{c}77.00 \mathrm{c} \\
\mathrm{AB}\end{array}$ & $\begin{array}{c}85.00 \mathrm{~d} \\
\mathrm{~A}\end{array}$ & $\begin{array}{c}77.67 \mathrm{~b} \\
\mathrm{AB}\end{array}$ \\
\hline
\end{tabular}

Keterangan : Angka yang diikuti dengan huruf kecil yang sama pada kolom yang sama atau huruf kapital yang sama bada baris yang sama menunjukkan tidak berbedanyata menurut uji jarak berganda Duncan pada taraf nyata $5 \%$. 
Hasil analisis ragam menunjukkan bahwa terdapat pengaruh konsentrasi $\mathrm{GA}_{3}$ dan lama perendaman terhadap potensi tumbuh maksimum jagung manis. Pengaruh interaksi dapat dilihat pada perendaman 3 dan 6 jam, bahwa pemberian giberelin dengan konsentrasi 150 ppm tidak terlalu menurunkan daya berkecambah dibandingkan tanpa perendaman pada suhu $16-18{ }^{\circ} \mathrm{C}$, sementara pada suhu 20-22 ${ }^{\circ} \mathrm{C}$, perendaman 6 jam tidak terlalu menurunkan daya berkecambah. Konsentrasi 100 ppm giberelin pada perendaman 9 jam menurunkan daya berkecambah tidak lebih buruk dibandingkan tanpa perendaman pada suhu 16$18{ }^{\circ} \mathrm{C}$, sementara konsentrasi 50 dan 100 ppm pada perendaman 9 jam pada suhu 20-22 ${ }^{\circ} \mathrm{C}$ menurunkan daya berkecambah tidak lebih buruk. Uji DMRT menunjukkan bahwa pada konsentrasi $\mathrm{GA}_{3} 100 \mathrm{ppm}$ dengan lama perendaman 6 jam menghasilkan persentase potensi tumbuh maksimum yang tertinggi yaitu sebesar $99.33 \%$ pada suhu $16-18{ }^{\circ} \mathrm{C}$ dan $99.33 \%$ pada suhu $20-22{ }^{\circ} \mathrm{C}$ (Tabel 7 dan 8 ).
Yamaguchi (2008)melaporkan bahwa ada duafungsi giberelin selama perkecambahan benih. Giberelin selain diperlukan untuk meningkatkan potensi tumbuh dari embrio dan sebagai promotor perkecambahan, juga diperlukan untuk mengatasi hambatan mekanik oleh lapisan penutup benih karena terdapatnya jaringan disekeliling radikula. Hedden dan Croken (1992) serta Weiss dan Ori (2007) dalam laporannya menyatakan bahwa salah satu efek fisiologis dari giberelin adalah sebagai pendorong aktivitas enzim-enzim hirolitik dalam proses perkecambahan benih. Selama proses perkecambahan benih, embrio yang sedang berkembang melepaskan giberelin kelapisan aleuron. Giberelin tersebut menyebabkan terjadinya transkripsi beberapa gen penanda enzim-enzim hidrolitik diantaranya a-amilase. Lebih lanjut enzim tersebut masuk ke endosperma dan menghidrolisis pati dan protein sebagai nutrisi utama bagi perkembangan embrio.

Tabel 7. Pengaruh interaksi perlakuan konsentrasi giberelin dan lama perendaman terhadap persentase potensi tumbuh maksimum pada suhu $16-18^{\circ} \mathrm{C}$.

\begin{tabular}{|c|c|c|c|c|}
\hline \multirow{2}{*}{$\begin{array}{l}\text { Lama Perendaman } \\
\text { KonsentrasiGA }_{3}\end{array}$} & \multicolumn{4}{|c|}{ Potensi TumbuhMaksimum(\%) } \\
\hline & $\mathrm{p}_{0}(0$ jam $)$ & $\mathrm{p}_{1}(3$ jam $)$ & $\mathrm{p}_{2}(6$ jam $)$ & $\mathrm{p}_{3}(9$ jam $)$ \\
\hline \multirow[b]{2}{*}{$\mathrm{g}_{0} \quad(0 \mathrm{ppm})$} & $75.00 \mathrm{c}$ & $77.00 \mathrm{c}$ & $81.67 \mathrm{c}$ & $76.33 \mathrm{c}$ \\
\hline & B & B & A & B \\
\hline \multirow{2}{*}{$\mathrm{g}_{1} \quad(50 \mathrm{ppm})$} & $80.00 \mathrm{~b}$ & $87.00 \mathrm{~b}$ & $96.00 \mathrm{~b}$ & $83.67 \mathrm{~b}$ \\
\hline & $\mathrm{C}$ & B & A & $\mathrm{CB}$ \\
\hline \multirow{2}{*}{$\mathrm{g}_{2}(100 \mathrm{ppm})$} & $86.67 \mathrm{a}$ & $90.00 \mathrm{a}$ & 99.33 a & $90.00 \mathrm{a}$ \\
\hline & $\mathrm{C}$ & B & A & B \\
\hline \multirow{2}{*}{$\mathrm{g}_{3}(150 \mathrm{ppm})$} & $76.00 \mathrm{c}$ & $83.00 \mathrm{~b}$ & $88.67 \mathrm{~b}$ & $77.67 \mathrm{c}$ \\
\hline & C & B & A & C \\
\hline
\end{tabular}

Keterangan : Angka yang diikuti dengan huruf yang sama pada kolom yang sama menunjukkan tidak berbedanyata menurut uji jarak berganda Duncan pada taraf 5\%, huruf kapital dibaca arah horizontal dan huruf kecil dibaca arah vertikal.

Tabel 8. Pengaruh interaksi perlakuan konsentrasi giberelin dan lama perendaman terhadap persentase potensi tumbuh masimum pada suhu $20-22^{\circ} \mathrm{C}$.

\begin{tabular}{ccccc}
\hline \multirow{2}{*}{$\begin{array}{c}\text { Lama Perendaman } \\
\text { KonsentrasiGA }\end{array}$} & \multicolumn{4}{c}{ Potensi Tumbuh $(\%)$} \\
\cline { 2 - 5 } $\mathrm{g}_{0}(0 \mathrm{ppm})$ & $\mathrm{p}_{0}(0 \mathrm{jam})$ & $\mathrm{p}_{1}(3 \mathrm{jam})$ & $\mathrm{p}_{2}(6 \mathrm{jam})$ & $\mathrm{p}_{3}(9 \mathrm{jam})$ \\
\hline & $72.67 \mathrm{c}$ & $77.00 \mathrm{c}$ & $90.00 \mathrm{c}$ & $74.33 \mathrm{c}$ \\
$\mathrm{g}_{1}(50 \mathrm{ppm})$ & $\mathrm{B}$ & $\mathrm{B}$ & $\mathrm{A}$ & $\mathrm{B}$ \\
& $78.00 \mathrm{~b}$ & $84.33 \mathrm{~b}$ & $92.67 \mathrm{~b}$ & $84.33 \mathrm{~b}$ \\
$\mathrm{~g}_{2}(100 \mathrm{ppm})$ & $\mathrm{C}$ & $\mathrm{B}$ & $\mathrm{A}$ & $\mathrm{B}$ \\
& $83.00 \mathrm{a}$ & $89.67 \mathrm{a}$ & $99.33 \mathrm{a}$ & $93.00 \mathrm{a}$ \\
$\mathrm{g}_{3}(150 \mathrm{ppm})$ & $\mathrm{C}$ & $\mathrm{B}$ & $\mathrm{A}$ & $\mathrm{B}$ \\
& $73.67 \mathrm{c}$ & $77.00 \mathrm{c}$ & $85.00 \mathrm{~d}$ & $77.67 \mathrm{c}$ \\
\hline
\end{tabular}

Keterangan : Angka yang diikuti dengan huruf yang sama pada kolom yang sama menunjukkan tidak berbedanyata menurut uji jarak berganda Duncan pada taraf 5\%, huruf kapital dibaca arah horizontal dan huruf kecil dibaca arah vertikal. 


\section{Kesimpulan}

Konsentrasi dan lama perendaman giberelin dapat meningkatkan daya berkecambah, kecepatan tumbuh, keserempakan tumbuh, dan potensi tumbuh maksimum pada benih tanaman. Peningkatan performa kecambah akibat efek aplikasi giberelin tidak dipengaruhi oleh suhu.

\section{Daftar Pustaka}

Badan Pusat Statistik (BPS), 2015. Data Produksi Jagung di Indonesia Tahun 2012 -2014. Jakarta.

Bakrie A. H. 2006. Respon Tanaman Jagung Manis (Zea mays Saccharata) Varietas Super Sweet terhadap Penggunaan Mulsa dan Pemberian Kalium. Prosiding Seminar Nasional Sainsdan Tekhnologi II 2008. Universitas Lampung. Lampung

Bradbeer, J.W. 1988. Seed Viability And Vigour. Seed Dormancy and Germination. Blackie and Son Ltd

Farooq, M., T. Aziz, A. Wahid, D.J. Lee, and K.H.M. Siddique. 2009. Chilling tolerance in maize: agronomic and physiological approaches. Corp and Pasture Science, CSIRO Publishing.

Gomez, K. A. and A. A. Gomez. 1995. Prosedur Statistik Untuk Penelitian Pertanian. Penerjemah Endang Sjamsudin, Justika S. Baharsjah; pendamping Andi Hakim Nasution. Universitas Indonesia Press. Jakarta

Hedden P. and J.S. Croker. 1992. Regulation of gibberellin biosynthesis in maize seedlings. Progress in Plam Growth Regulation, 534544 (C) 1992 Kluwer Academic Publishers.

Kamil, J. 1979. Teknologi Benih 1. Angkasa Raya. Bandung.

Kucera, B., M. A. Cohn, and G.H. Metzger. 2005. Plant hormone interactions during seed dormancy release and germination. Seed Science Research. 15:281- 307

Lesilolo, M. K., J. Riry, dan E. A. Matatula. 2013. Pengujian viabilitas dan vigor benih beberapa jenis tanamanyang beredar di pasaran kota Ambon. Agrologia, 2(1): 1 - 9.

Miedema, P. 1982. The effects of low temperature on zea mays. Advances in agronomy, vol 35 Foundation for
Agricultural Plant Breeding Wageningen, The Netherlands

Milosevic, M., M. Vujakovic and D. Karagic. 2010 Vigour Tests As Indicators Of Seed Viability

Mukti, A. 2013. Pengaruh konsentrasi giberelin dan lama perendaman terhadap viabilitas dan vigor benih jagung (Zea mays L.)kadaluarsa. Skripsi. Fakultas Pertanian Universitas Teuku Umar. Meulaboh.

Nirmala D., M. T. Mulyati, T. A.Bakar, M. M. Zainal. 2012. Pengembangan Model Usaha Jagung Terpadu Di Kabupaten Takalar. Bagian Ilmu dan Teknologi Pangan, Fakultas Pertanian, Universitas Hasanuddin. Jurnal Teknologi

Novira, F., Husnayetti, dan S. Yoseva. 2015. Pemberian pupuk limbah cair biogas dan urea, TSP, KCL terhadap pertumbuhan dan produksi tanaman jagung manis (Zea mays saccharata Sturt). Jurnal Teknologi

Putri, H. A. 2011. Pengaruh Pemberian Beberapa Konsentrasi Pupuk Organik Cair Lengkap (POCL) Bio Sugih Terhadap Pertumbuhan dan Hasil Tanaman Jagung Manis (Zea mays Saccharata Sturt.). Skripsi. Fakultas Pertanian. Universitas Andalas Padang.

Rubatzky, V. E, dan M. Yamaguchi.1995. Sayuran Dunia : Prinsip, Produksi, dan Gizi. Jilid ke-1. Herison C, penerjemah. Bandung (ID): ITB Press. Terjemahan dari: World Vegetables: Principles, Production, and Nutritive Values. Santoso MB. 2004. Efesiensi energi dan produktivitas pada tumpangsari

Rusmin, D.,F. C. Suwarno, dan I. Darwati. 2011. Pengaruh pemberian ga3 pada berbagai konsentrasi dan lama imbibisi terhadap peningkatan viabilitas benih purwoceng (pimpinella pruatjan molk). Jurnal Littri 17(3) : 89-94.

Sabhan, M. 2013.Study On Some Aspects Of Seed Viability And Vigor. Int. Journal of Advance Biol Biom Res. 2013; 1(12):16921697

Sutopo, L. 2012. Teknologi Benih. Rajawali Jakarta

Syukur dan Rifianto.2014. Jagung Manis. Penebar Swadaya. Jakarta.

Tefa, A. 2017. Uji viabilitas dan vigor benih padi (Oryza sativa, L.) selama penyimpanan pada tingkat kadar air yang berbeda. Savana Cendana, 2(3): 48 - 50. 
Weiss, D. and N. Ori. 2007. Mechanisms of cross talk beetween gibberellin and other hormones. Plant Physiology.

Yamaguci, S. 2008. Gibberellin Metabolism and its Regulation. Annu. Rev. Plant Biol. 2008. 59:225-51
Yanfang, S., Wang, W., Xie, J., Liang, Z. 2017. Biological Characteristics and Germination Conditions of Gentianae macrophylla Seeds under Different Storage and Seed Treatments. Journal of Agriculture \& Biology . 6/30/2017, Vol. 19 Issue 3, p502-508. 7p. 